NBER WORKING PAPER SERIES

\title{
STATE LOTTERIES AND CONSUMER BEHAVIOR
}

\author{
Melissa Schettini Kearney \\ Working Paper 9330 \\ http://www.nber.org/papers/w9330 \\ NATIONAL BUREAU OF ECONOMIC RESEARCH \\ 1050 Massachusetts Avenue \\ Cambridge, MA 02138 \\ November 2002
}

The author gratefully acknowledges the helpful comments of Daron Acemoglu, Joshua Angrist, David Autor, Peter Diamond, Amy Finkelstein, Michael Greenstone, Jonathan Gruber, Jonathan Guryan, Mark Lewis, Sendhil Mullainathan, Cynthia Perry, and seminar participants at the Massachusetts Institute of Technology, Brown University, Princeton University, and Wellesley College. Special thanks to the Bureau of Labor Statistics (BLS) CEX division, especially Steve Henderson, Eric Keil, and Wolf Weber, who were extraordinarily helpful in facilitating access to confidential BLS data. Any opinions expressed are those of the author and not of the BLS. Dean Gerstein of NORC went out of his way to provide confidential NORC data in a timely manner. Thanks also to Brett Toyne of the Multi-State Lottery Association and employees at various state lottery agencies for assistance compiling lottery jackpot and game information. Patrick Lo provided research assistance in the processing of jackpot data. Financial assistance was provided by the National Science Foundation and the Harry S. Truman Foundation through graduate school fellowships. The views expressed herein are those of the authors and not necessarily those of the National Bureau of Economic Research.

(C) 2002 by Melissa Schettini Kearney. All rights reserved. Short sections of text, not to exceed two paragraphs, may be quoted without explicit permission provided that full credit, including $\bigcirc$ notice, is given to the source. 
State Lotteries and Consumer Behavior

Melissa Schettini Kearney

NBER Working Paper No. 9330

November 2002

JEL No. D1, H1, H3, H8

\section{ABSTRACT}

Despite considerable controversy surrounding the use of state lotteries as a means of public finance, little is known about their consumer consequences. This project investigates two central questions about lotteries. First, do state lotteries primarily crowd out other forms of gambling, or do they crowd out non-gambling consumption? Second, does consumer demand for lottery games respond to expected returns, as maximizing behavior predicts, or do consumers appear to be misinformed about the risks and returns of lottery gambles? Analyses of multiple sources of micro-level gambling data demonstrate that lottery spending does not substitute for other forms of gambling. Household consumption data suggest that household lottery gambling crowds out approximately $\$ 38$ per month, or two percent, of other household consumption, with larger proportional reductions among low-income households. Demand for lottery products responds positively to the expected value of the gamble, controlling for other moments of the gamble and product characteristics; this suggests that consumers of lottery products are not simply uninformed, but are perhaps making fully-informed purchases.

Melissa Schettini Kearney

Department of Economics

Wellesley College

Wellesley, MA 02481

and NBER

mkearney@wellesley.edu 


\section{Introduction}

In the past three decades, the prevalence and scale of state lotteries have expanded dramatically. The first modern state lottery was introduced in New Hampshire in 1964. By 1973, seven states operated state lotteries and consumers spent a total of $\$ 2.1$ billion on lottery products (in year 2000 dollars). ${ }^{1}$ By 1999, there were 38 state lotteries in operation, and consumers spent a total of $\$ 37$ billion. This total represents an annual average of $\$ 226$ per adult living in a lottery state, or $\$ 370$ per household nationwide. This is more than the average household spent in 1999 on alcoholic beverages or on tobacco products and supplies. It is more than twice the amount households spent on reading materials. And it is roughly equal to what the average household spent on life and other personal insurance. ${ }^{2}$

As the expansion of state lotteries continues, there is substantial public controversy surrounding the use of lotteries as a means of raising public funds. Opponents argue that state lotteries prey on minorities and the poor and that spending on state lotteries displaces consumption and savings. Some worry that governments are "tricking" people with a "sucker's bet," exploiting misinformation on the part of consumers. ${ }^{3}$ Supporters of state lotteries counter that people from all demographic groups play the lottery. They argue that people demand gambling products and a state lottery capitalizes on that demand by providing a product that substitutes for other forms of gambling. Some characterize lottery sales as voluntary purchases of entertainment goods.

Despite the controversy, there is virtually no empirical research into the validity of the claims on either side of the debate. This paper fills that gap by addressing two central questions. First, do lotteries simply crowd out other gambling expenditures, or does the presence of a state lottery lead to a reduction in other forms of household spending? Second, does consumer demand for lottery games respond to expected returns, as maximizing behavior predicts, or do consumers appear to be misinformed about the risks and returns of lottery gambles?

\footnotetext{
${ }^{1}$ Clotfelter et al. (1999), p. 100. Their figures are in year 1997 dollars.

${ }^{2}$ United States Bureau of Labor Statistics (2001), Table A.

${ }^{3}$ To cite two opponents: "In fact, state lotteries ... are mechanisms by which the state seduces its citizens with the promise of riches, suckering them into gambling away their income and their unemployment checks on games that offer an almost infinitesimal chance of winning big." Robyn Gearey in The New Republic, May 1997; "The lottery may seem like 'funny money', but it is in effect taxation, taken through a con-trick." The Economist, Nov 18, 2000, on Britain's National Lottery.
} 
The paper first investigates how household gambling behavior responds to the introduction of a state lottery. I conduct two different analyses to answer this question. The first is an analysis of micro-level data on household gambling from confidential Bureau of Labor Statistics (BLS) Consumer Expenditure Survey (CEX) - Diary Survey files from 1982 to 1998. During this time 21 states implemented a state lottery. I exploit the variation across states in the timing of state lottery introduction to compare the change in gambling expenditures among households in states that implement a lottery to the change among households in states that do not. The data demonstrate that total household gambling is increased after a state lottery is introduced, which implies that households are not completely financing lottery gambling by substituting away from other forms of gambling. A complementary analysis looks at data on adult gambling behavior from two national surveys, a 1998 survey conducted by the National Opinion Research Council (NORC) and a 1975 survey conducted by researchers at the University of Michigan. These data confirm that adults do not reduce their participation in previously-existing forms of gambling after a state lottery is introduced.

If consumers respond to the presence of a state lottery with new gambling, then they must substitute away from other consumption. I analyze BLS CEX - Interview Survey data from 1984 to 1998 to investigate to what extent this is true. I exploit the variation across states in the timing of state lottery introduction to compare the change in household expenditures among households in states that implement a lottery to the change among households in states that do not. The analysis finds that household spending on lottery tickets is financed completely by a reduction in non-gambling consumption. The introduction of a state lottery is associated with a decline of $\$ 115$ per quarter in household non-gambling consumption. This figure implies a monthly reduction of $\$ 23$ in per-adult consumption, which compares to average monthly sales of $\$ 18$ per lottery-state adult. The response is most pronounced for low-income households, which on average reduce non-gambling consumption by three percent. Among households in the lowest income third of the CEX sample, the data demonstrate a statistically significant reduction in expenditures on food eaten in the home (3.1 percent) and on home mortgage, rent, and other bills (6.9 percent).

The final analysis of the paper is an evaluation of whether lottery consumers appear to be making informed choices. The answer to this question is important to determining whether the shift in household consumption is consumer-welfare enhancing. Lottery gambling is part 
investment, as consumers are making choices over risky assets, and it is part entertainment. Assuming that the entertainment and pecuniary components of the lottery gamble are separable, maximizing behavior predicts that consumer demand for lottery products should depend positively on its expected return, holding constant game characteristics. To evaluate whether this prediction holds, I analyze weekly sales and characteristics data from 91 lotto games from 1992 to 1998 . The analysis suggests that sales are positively driven by the expected value of a gamble, controlling for higher-order moments of the gamble and non-wealth creating characteristics. This finding is robust to alternative specifications, including controlling for unobserved product fixed effects. In addition, I find that consumers respond to non-wealth creating, "entertaining" game features. Together, these two findings suggest that consumers are at least partly - and potentially fully - informed, rational consumers. It is consistent with these findings to claim that consumers derive an entertainment equal to the price of the gamble (one minus expected value), and then, insofar as they are making investments, they are informed evaluators of gambles.

The paper proceeds as follows. Section 2 presents an overview of state lotteries in the United States. It briefly discusses the history and operation of state lotteries and then presents micro-level evidence about lottery gambling. The section concludes with a theoretical discussion about the market for lottery products. Section 3 reviews related evidence. Section 4 discusses the impact of state lotteries on household expenditures, looking first at gambling behavior and then at household non-gambling consumption. Section 5 investigates consumer demand for lottery products as a function of game characteristics. And finally, section 6 provides concluding comments.

\section{State lotteries in the United States}

\subsection{History and operation}

The state of New Hampshire ushered in the era of the modern lottery by introducing a state lottery in 1964. ${ }^{4}$ Inspired by New Hampshire's lead, New York and New Jersey soon introduced

\footnotetext{
${ }^{4}$ Previously, lotteries played a role in raising money for such notable projects as Harvard College, the Continental Army, and public works undertakings throughout the Colonial period. A scandal involving the Louisiana Lottery in 1894 led to the prohibition of lotteries for seven decades. See Clotfelter et al. (1999) for a more complete discussion of the history and operation of state lotteries.
} 
their own state lotteries. Cross-border lottery sales place pressure on neighboring states to implement their own state lottery. ${ }^{5}$ Accordingly, the spread of lotteries primarily followed a geographical pattern, spreading first across the Northeast, then to the West, and finally to the Midwest and South. By 1996, 37 states and the District of Columbia operated a state lottery. Appendix Table 1 lists implementation dates.

In each case the state ended its former prohibition of lotteries and established a state agency as the sole provider of lottery products. All states use the profits from the state lottery operation as a source of revenue. Ten of the 38 state lotteries allocate lottery revenues to general funds; 16 earmark all or part of lottery revenues to education; and the remainder earmark for a wide variety of uses, some specific and others broad. On average, a dollar wagered on a state lottery game returns 33 cents of profit to the state. This profit can be likened to an excise tax levied at a certain rate on the purchases of a particular product. Assuming a five percent average state income tax, the implicit tax rate on state lotteries in 1997 was approximately 61 percent. $^{6}$ In spite of this, the lotteries' contributions to state budgets are modest. In 1997, the contribution of state lottery funds to total own-source general revenues ranged between .41 percent in New Mexico to 4.07 percent in Georgia. ${ }^{7}$

\subsection{Lottery gambling: micro-level evidence}

Consumer spending on state lottery products in 1999 totaled $\$ 37$ billion in year 2000 dollars. The 2000 National Gaming Survey reports that 72 percent of American adults purchased some kind of lottery product during the year, 28 percent played at least once a week, and 14 percent played more than once a week.

\footnotetext{
${ }^{5}$ This explanation finds empirical support in Berry and Berry (1990), which finds that the probability that a state will adopt a lottery increases in the number of its neighbors that have previously adopted lotteries even controlling for internal characteristics. There is anecdotal support as well. Both Governor Don Siegelman of Alabama and Governor Jim Hodges of South Carolina campaigned in 1998 on pro-lottery platforms. Sigelman argued, "Hundreds of millions of Alabama dollars have left Alabama to buy lottery tickets in Florida and Georgia. I say it's time for us to keep that money here so that our schools can have pre-kindergarten, our schools can have computers, and our children can go to college tuition-free."

${ }^{6}$ Clotfelter and Cook (1989) calculate that the average excise tax on four products in 1985, including federal, state, and local taxes was as follows: beer - 15 percent, wine - 17 percent, liquor - 43 percent, and tobacco products - 49 percent.

${ }^{7}$ National Gambling Impact Study Commission (1999), pp. 2-4.
} 
Micro-level evidence is available from two independent surveys: the 1975 National Survey of Adult Gambling conducted by Kallick et al. at the University of Michigan and the 1998 National Survey on Gambling conducted by the National Opinion Research Council (NORC) under contract with the National Gambling Impact Study Commission. The Kallick et. al. (1975) data consist of 1,749 completed interviews covering participants' lifetime and past-year gambling behavior. The NORC (1998) data contain information about the gambling behavior of 2,417 adults from a random-digit dial sample. ${ }^{8}$ In order to develop estimates of annual lottery expenditures from the information obtained by the NORC survey, I adopt a set of assumptions used by Clotfelter and Cook (1999). ${ }^{9}$ Clotfelter and Cook (1999) calculate that estimates of national expenditures based on the NORC (1998) survey and this set of assumptions amount to only 86 percent of recorded sales. The reader should keep in mind that actual expenditures exceed the amounts discussed in this section. The reported expenditure differences across groups reflect true differences under the assumption that groups do not under-report lottery expenditures differentially.

Table 1 presents descriptive information from the NORC survey. The data reveal four general facts. First, people in all demographic groups participate in lottery gambling, where participation is defined broadly as any gambling during the year. Fifty-five percent of males and 47 percent of females report participation. The reported participation rate is 52.4 percent among whites, 42.3 percent among blacks, and 58.8 percent among Hispanics. Table 1 also shows that participation extends across all income groups.

Second, black respondents spend nearly twice as much on lottery tickets as do white or Hispanic respondents. Black women report higher average expenditures than white and Hispanic women as well as white and Hispanic men, in all income groups. The average reported expenditure among blacks is $\$ 200$ per year, $\$ 476$ among those who participate. Black men have the highest average expenditures. In particular, the fifteen black male high-school dropouts in the sample report average annual expenditures over $\$ 1,000$; among the ten who participated in

\footnotetext{
${ }^{8}$ Clotfelter and Cook (1999) use the NORC combined survey which includes the RDD sample and a gambling patron sample. To preserve the representativeness of the survey sample, I only use the random sample for my analyses.

${ }^{9}$ These assumptions first require assigning discrete values to the reported frequencies: 300 to "about every day", 100 to "1 to 3 times per week," 18 to "once or twice a month," 8 to "a few days all year," and 1 to "only one day in the past year". Second, if a respondent reports playing multiple types of games, it is assumed they played lotto no more than once per week.
} 
lottery gambling during the year, annual expenditures are over $\$ 2,000$. In the 1999 Current Population Survey March file, mean income among this demographic group is $\$ 10,400$.

Third, average annual lottery spending in dollar amounts is roughly equal across the lowest, middle, and highest income groups. Reported annual expenditures are $\$ 125, \$ 113$, and $\$ 145$, respectively. This implies that on average, low-income households spend a larger percentage of their wealth on lottery tickets than other households.

Fourth, lottery participation and spending is much higher in states with state lotteries than in states without lotteries. As shown in Table 1, participation in lottery gambling among adults living in lottery states is 54.7 percent, versus 25.2 in non-lottery states. The difference is statistically significant with a $t$-statistic of 12.0. Average annual lottery expenditures are estimated to be $\$ 128$ among residents of lottery states and $\$ 47$ among residents of non-lottery states. The difference is statistically significant, with a $t$-statistic of 4.62. By 1998, every continental state without a lottery bordered at least one state with one, making out-of-state lottery gambling feasible for a sizeable number of adults. The difference is much more pronounced in the 1975 survey when only 12 states operated lotteries: 50 percent of adults living in states with lotteries participated compared to only 7 percent of adults in non-lottery states.

\subsection{Market conditions: theory}

\subsubsection{The product market and prices}

In a perfect market, characterized by full competition and complete information, gambling products are supplied competitively by private firms and priced at marginal cost. For simplicity, assume that all gambles with the same expected value (EV) are valued equally among consumers. There is no differential entertainment value, nor utility over risk. Define the relevant price to be the price of a gamble with an $\mathrm{EV}$ of $\$ 1$. Consumers take the private market price as given, $P_{p}=M C$, and products are allocated efficiently. Contrast this environment to one in which there is only one gambling product and it is supplied by a monopolistic state lottery agency at the monopoly price $P_{s}$. Households face a higher price of gambling, $P_{s}>P_{p}$, so if demand is not fully inelastic, they purchase fewer gambles. 
Historically, states have not established state lottery monopolies in a previously competitive environment. The gambling environment in a state pre-state-lottery can be described as one in which all lottery games are illegal within the state, but households are offered a limited supply of alternative gambling forms: illegal "numbers" betting, legal casinos, horse tracks or charitable gambling, or out-of-state lottery products. In this "limited" market, the price of gambling faced by household $h$ is

$$
P_{0 h}=\min \left\{P_{n}+\alpha_{n h}, P_{c}+\alpha_{c h}, P_{b}+\alpha_{b h}\right\}
$$

where $P_{0 h}$ is the minimum price of gambling among the three available options. $P_{n}$ is the average price of a $\$ 1 \mathrm{EV}$ gamble offered by numbers bookkeepers; $P_{c}$ is the average price of a $\$ 1 \mathrm{EV}$ gamble offered by casinos or other legal venues; and $P_{b}$ is the average price of a $\$ 1 \mathrm{EV}$ gamble offered by lotteries operated in bordering states. The second component $\alpha_{-h}$ is the transaction cost to the household of the particular gambling type, which includes any transportation cost as well as any stigma associated with the particular form of gambling.

The establishment of a monopolistic state lottery introduces a new gamble at a price to household $h$ of $P_{s h}=P_{s}+\alpha_{s h}$. The relevant price of a $\$ 1 \mathrm{EV}$ gamble for household $h$ becomes $P_{I h}$ $=\min \left\{P_{s h}, P_{0 h}\right\}$. If $P_{s h}$ is time-invariant, $P_{l h}-P_{0 h}<=0$, since alternatives remain available. In many cases the difference will be less than zero as lottery gambling itself involves minimal transportation and arguably stigma. (We might suspect that $P_{s h}$ will change; alternatives could become less costly if the introduction of a lottery reduces the stigma of gambling, thereby

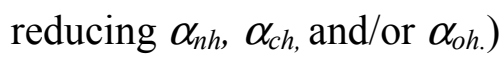

If consumers prefer a corner solution of no gambling or some fixed level of gambling losses, there will be no effect on consumer behavior. However, under the usual assumptions regarding consumer utility, the price and income effects work in the same direction for gambling, and consumers will increase their gambling expenditures. Because the magnitude of the price change varies across households, the response will be heterogeneous. (Once we acknowledge that gambles have differential entertainment values, the household response to state lotteries becomes more varied.) For consumption, the price and income effects work in opposite directions; depending on preferences, spending on non-gambling consumption will fall, rise, or stay the same. If consumers are rational and informed, and externalities are not relevant, then the reallocation of the household budget induced by the introduction of a state lottery will increase household welfare. 


\subsubsection{Consumer rationality and information}

Among the 38 operating state lotteries in 2000, the average pay-out rate was 52 percent, ranging from a low of 26 percent in Delaware to a high of 71 percent in Nebraska. ${ }^{10}$ When a lotto jackpot grows sufficiently large through rollovers accumulating from a series of drawings in which no one wins, it may be possible to place a bet with a positive return (Thaler and Ziemba, 1988). But such occasions are rare, and most lottery bets placed are on unfavorable gambles. Why would a risk-averse consumer purchase such a gamble?

The first explanation is that consumers know state lotteries offer unfair gambles but derive entertainment value from playing them. In this case, consumers are fully rational and informed decision makers and the only concern for economists is that the price is set inefficiently high at the monopoly price. An alternative explanation is that consumers are misinformed. In some instances, the odds of winning the jackpot might not be clear. Moreover, the advertised prize is typically the undiscounted prize amount, not the present discounted value of the annuity prize. ${ }^{11}$ In addition, it might be the case that consumers know that the odds of winning are very small, but they do not actually understand the implications. Psychologists have documented an "illusion of control," whereby agents deny the operation of chance, believing that they can choose winning numbers through skill or foresight (Langer 1975, 1978). According to Kahneman and Tversky's (1979) prospect theory, agents overweight small probabilities and underweight large probabilities. In this line of thought, the agent is rational, but his objective function is not the objective function of expected utility theory. ${ }^{12}$ If consumers are not making informed decisions, the welfare consequences of raising government revenue from lottery purchases is ambiguous.

\subsubsection{Intra-household externalities}

\footnotetext{
${ }^{10}$ LaFleur's 2001 World Lottery Almanac.

${ }^{11}$ For example, when the Powerball jackpot was advertised to be $\$ 266$ million, the present discounted value of the 25 -year annuity was $\$ 147$ million (assuming a six percent interest rate.)

${ }^{12}$ An additional concern not addressed in this paper is addiction. It is widely argued that gambling is addictive for some people, and lottery gambling is no exception. Becker and Murphy (1988) and Gruber and Koszegi (2000) argue that addiction does not necessarily imply irrationality. But, Gruber and Koszegi (2000) also argue that addiction amplifies the effects of irrationality. If lottery players are addicted consumers, the welfare consequences of state lotteries are ambiguous.
} 
The above discussion focuses on whether the consumer makes choices that unknowingly harm him, either because of irrationality or misinformation. An additional concern is whether the agent makes choices that harm those around him, in particular, other members of his household. Traditionally, economists have considered the family or household as a single unit that maximizes a common objective function subject to the family budget constraint. But recent evidence suggests that the household is a collective, not a unitary, entity and that expenditures depend in part on who controls the household income (Duflo (2000), Browning and Chiaporri (1998), Udry (1996)). If the members of the household do not share a common utility function, any increase in gambling expenditures might come at the expense of the well-being of those not in control of the household finances.

\section{Related evidence}

This paper provides to the author's knowledge the first empirical test of the consequences of state lotteries for consumer behavior. Imbens et al. (1999) estimate the effect of lottery winnings on players' subsequent earnings, labor supply, consumption, and savings; this is a distinct question from the impact of lottery exposure on consumption. Clotfelter and Cook's 1989 book provides a comprehensive description of the legalization, provision, marketing, and implicit taxation of state lotteries. Clotfelter et al. (1999) provide a more recent overview of lottery operations, with particular attention to who plays the lottery, how the lotteries are marketed, and what kinds of policy alternatives exist for state and federal policymakers. It discusses survey evidence on lottery gambling based on the 1998 NORC survey discussed in the previous section. Worthington (2001) documents demographic predictors of lottery gambling in Australia and concludes that the implicit lottery tax is regressive.

There has been some limited previous investigation into the sales of lottery products. Clotfelter and Cook (1990a) provide a cursory look at the effect of changing prices and payoffs on lottery ticket sales. The authors observe 170 consecutive drawings of the Massachusetts lotto game in the mid-1980s and find that for each $\$ 1,000$ increase in the predicted jackpot due to “rollover", sales increase by \$333. Garrett and Sobel (1999) analyze the demand for lottery games using a 1995 cross-section of 216 lottery games in the United States. The authors make a 
series of assumptions, including indifference across lottery games, that yield the following result: the expected utility for any lottery player in a state can be represented by equating the odds ratio of winning the top prize in games $G$ and $g$ to the utility of winning the top prize in game $g$. The authors use the cubic approximation of Golec and Tamarkin (1998) to estimate a model of expected utility; they estimate the odds ratio as a linear function of the top prize, the square of the top prize, and the cube of the top prize. The estimated coefficients on the prize and cubic prize are significantly greater than zero, and the coefficient on the square of the prize is significantly less than zero. The authors interpret this as evidence of a cubic utility function, similar to that proposed by Friedman and Savage (1948) and found by Golec and Tamarkin (1998) in the context of betting at horse tracks.

In addition to the stringency of the identifying assumptions underlying Garrett and Sobel (1999), the empirical analysis of the paper has three major limitations. First, all on-line games are included in the estimation sample. The result thus relies on the very strong assumption of a representative agent across game types. Second, the authors do not control for non-wealth creating characteristics of games. If consumers enjoy playing lottery games for reasons other than the gamble itself, omitting game features from the estimation is problematic. And finally, the key variable in their analysis, jackpot prize, is measured with systematic error. For games with variable jackpots, the authors estimate average prize using annual sales data and the percent of sales that is allocated to the prize. This approach does not incorporate the weekly variation in jackpot size within a game for games with rolling jackpots, but it uses the true jackpot amount for fixed jackpot games.

Gulley and Scott (1993) and Forrest, Gulley, Simmons (2000) analyze the demand for lotteries from the perspective of revenue maximization, rather than consumer preferences. Gulley and Scott (1993) examine drawing level sales data from four lotto games in three states from the late eighties to early nineties. The authors estimate demand as a function of price, defined as one minus the expected value, without controlling for higher-order moments or non-wealth creating characteristics. The resulting price elasticities suggest that two games are setting price close to the revenue maximizing value, one is setting price too low and the other too high. Forrest, Gulley, Simmons (2000) similarly examine sale patterns in the first three years of the UK National Lottery to estimate the price elasticity of demand. Their long-run estimate is close to 
minus one, which they interpret as evidence that the UK government is maximizing lottery revenue.

\section{The impact of state lotteries on consumer expenditures}

Lottery betting is widespread and substantial, as documented in Section 2.2 above. This raises the question: does the introduction of a state lottery induce new gambling expenditures and thereby crowd-out non-gambling consumption? Or does it merely cause substitution away from existing gambling alternatives? I answer these questions with three separate analyses. First, I investigate how total household gambling expenditures respond after to the introduction of a state lottery. Second, I analyze how participation in various types of gambling changes. And third, I investigate how household non-gambling expenditures shift in response to the introduction of a state lottery. I investigate the impact on gambling activities and non-gambling consumption separately because there is no single data source containing detailed information about both household gambling and non-gambling consumption.

\subsection{How do state lotteries affect total household gambling?}

\section{Evidence from consumer diaries}

I investigate whether the introduction of a state lottery leads to increased household gambling using confidential Bureau of Labor Statistics (BLS) Consumer Expenditure Survey (CEX) Diary Survey data files from 1984 to 1999. All dollar values are adjusted to year 2000 dollars using the BLS Consumer Price Index. These files were accessed under an agreement with the BLS. The BLS CEX program consists of the quarterly Interview Survey and the two-week Diary Survey, each with its own independent sample of approximately 5,000 households (7,500 after 1998). The Diary Survey collects information about weekly household expenditures on frequently purchased small-item goods, including gambling expenditures. ${ }^{13}$

\footnotetext{
${ }^{13}$ The data is collected through diary forms that include the following written instructions: "Record all your consumer unit's expenses for the 7-day period indicated on the front page....Please use this diary to record purchases or expenses, no matter how small or inexpensive they are."
} 
Unfortunately, lottery gambling is drastically underreported in the CEX Diary Survey. ${ }^{14}$ Based on 1998 sales data compiled by LeFleurs Inc., adults living in lottery states averaged \$226 annually on lottery tickets. In contrast, CEX Diary respondents living in lottery states report an average of $\$ 0.71$ for the two-week interval. Assuming smooth annual expenditures, this implies mean annual lottery expenditures of only $\$ 36$. The underreporting is so severe that magnitudes implied by an analyses of this data are not reliable. However, the data can reveal whether total gambling expenses increase when a state lottery is introduced, even if it can not precisely tell us by how much. Furthermore, if underreporting is proportional across demographic groups, the CEX Diary data can reveal differential effects across groups.

Is total gambling higher in lottery states than in non-lottery states? The CEX Diary data suggest that both the unconditional probability of engaging in any type of gambling and total household gambling expenses are greater among residents in states with state lotteries than among residents in non-lottery states. ${ }^{15}$ It appears that these differences are not entirely due to differences in preferences: mean household gambling expenditures are higher post-lottery (\$2.17) than pre-lottery (\$0.87) among states that ever adopt lotteries; the $t$-statistic of the difference is 10.4 . This provides preliminary evidence that lottery gambling is not completely financed by substitution away from other forms of gambling.

To corroborate this initial finding, we turn to regression analysis. The analysis exploits the variation across states in the timing of state lottery introduction to evaluate whether the presence of a state lottery is associated with a change in household gambling. (I use the same empirical strategy in the analysis of non-gambling consumption below.) The strategy is to compare the change in expenditures among households in states that implement lotteries to the change in expenditures among households in states that do not make the lottery transition in the same period. Relative to states that have not yet implemented a state lottery, or that did so in the past, this analysis identifies the incremental change in expenditures associated with the introduction of the lottery. During this time, 21 states switch status from non-lottery to lottery

\footnotetext{
${ }^{14}$ Starting in 1996 , the data files record lottery expenditures separately.

${ }^{15}$ The mean two-week gambling participation rate is 8.5 percent in states with a lottery at the time versus 1.9 percent in non-lottery states; the $t$-statistic of the difference is 50.3. Unconditional mean two-week gambling expenditures are $\$ 2.17$ in lottery states versus $\$ 0.71$ in non-lottery states; the $t$-statistic of the difference is -14.1.
} 
state; 16 states and the District of Columbia have lotteries in place the entire period; and the remaining 13 states are without a state lottery the entire period. ${ }^{16}$

The estimating equation takes the following form:

$$
y_{\mathrm{ijt}}=\alpha+\lambda\left(\text { LOTSTATE }_{\mathrm{jt}}+\mathbf{X}_{\mathrm{ijt}} \boldsymbol{\beta}_{1}+\mathbf{Z}_{\mathrm{jy}} \boldsymbol{\beta}_{2}+\mathbf{M}_{\mathrm{ijt}} \beta_{3}+\gamma_{\mathrm{jt}}+\omega_{\mathrm{y}}+v_{\mathrm{j}}+\varepsilon_{\mathrm{ijt}}\right.
$$

In the first analysis, $y_{\mathrm{ijt}}$ is defined as gambling expenditures for household $i$ in state $j$ in the twoweek time period $t$. In subsequent analyses, $y_{\mathrm{ijt}}$ is defined as total non-gambling consumption and then as spending on particular categories of goods, for household $i$ in state $j$ in reference period $t$. The regressor of interest is the LOTSTATE indictor. It is equal to one if there is a state lottery in the household's state of residency $j$ during the reference period $t$, and zero otherwise. (For quarterly observations, it is based on the presence of a lottery in the first month of the quarter.) The coefficient on LOTSTATE is interpreted as the causal effect of the presence of a state lottery on the dependent variable.

The vector $\mathbf{X}_{\mathrm{ijt}}$ consists of household level controls for family size, household income, urban status, number of persons less than 18 and over 64, and the sex, race, marital status, and education of the household head. The vector $\mathbf{Z}_{\mathrm{jy}}$ consists of controls for the state level of cigarette, beer, and gasoline taxes, which vary by year. This controls for differences in the prices of these goods that are not captured in either year or state effects. The vector $\mathbf{M}_{\mathrm{ijt}}$ consists of a series of dummy variables indicating the months of the year during which the household is observed; it is included in the estimation equation to control for seasonal spending effects. Finally, $\gamma_{\mathrm{jt}}$ is the monthly state unemployment rate in reference period $t$ (for quarterly observations, it is averaged over the quarter); $\omega_{\mathrm{y}}$ is a binary indictor for the year, which controls for any nationwide shocks to spending; and $v_{\mathrm{j}}$ is a dummy that captures fixed effects associated with state $j$.

The identifying assumption of equation (1) is that the implementation of the 21 state lotteries during this time period does not coincide with other state-level changes that are not controlled for in the regression but that might affect household expenditure behavior. An obvious candidate is changes in the legalization of other forms of gambling. Fortunately, changes in the

\footnotetext{
${ }^{16}$ The set of switching states consists of CO, CA, IO, OR, MO, WV, MT, KS, SD, VA, FL, WI, ID, IN, KY, MN, LA, TX, NE, GA, NM; the always-lottery states are NH, NY, NJ, CT, MA, MI, PA, MD, IL, ME, OH, RI, DE, VT, AZ; and the never-lottery states are AL, AK, AR, HI, ID, MS, NC, NV, OK, SC, TN, UT, WY.
} 
availability of other forms of gambling does not coincide with the timing of state lottery introduction. $^{17}$

Table 2 displays the results from estimating equation (1) for gambling behavior using CEX Diary data. ${ }^{18}$ Mean gambling expenditures and participation among households in states that do not have a lottery in place at the time are listed in columns 1 and 3, respectively. Column 2 reports coefficients from an OLS regression of equation (1) with expenditure level as the dependent variable. As expenditures constitute a limited dependent variable, interpreting the regression coefficient is not entirely straightforward. When Ordinary Least Squares (OLS) regression is used to estimate the equation for expenditure levels, observations with zero spending are included in the analysis and the estimated impacts combine the extensive and intensive margins. These effects are reported separately in columns 4, 5, and 6. Column 4 lists the coefficients from OLS estimation of equation (1) with the dependent variable defined to be "any gambling expenditures"; column 5 lists marginal effects from a Probit specification. The final column reports the coefficient on LOTSTATE when the dependent variable is the natural logarithm of expenditures. The coefficient necessarily captures changes on the intensive margin as the sample is conditioned on positive spending. To the extent that the introduction of a state lottery affects the extensive margin of gambling, the set of households with positive gambling expenditures is changed and the estimated effect on intensity is contaminated. ${ }^{19}$

The results in Table 2 confirm that the introduction of a state lottery leads households to increase total gambling expenditures and participation. For the overall sample, the estimated coefficient on LOTSTATE in the OLS levels specification reveals that two-week gambling expenditures increase by a reported $\$ 1.43$, off a mean of $\$ 0.71$. The results of OLS and Probit

\footnotetext{
${ }^{17}$ The legalization of casino gambling substantially lags the spread of state lotteries. Before the early 1990s, legal casinos only operated in Nevada and Atlantic City, New Jersey. Now they are legal in 28 states. Similarly, riverboat casinos did not begin operating legally until the first one opened in Iowa in 1991. Most Native American tribal gambling started after 1987, when the United States Supreme Court issued a decision confirming the inability of states to regulate commercial gambling on Indian reservations.

${ }^{18}$ With the exception that state unemployment rate is not controlled for in the analyses. State unemployment data were not available when the confidential BLS CEX Diary were accessed at BLS.

${ }^{18}$ Tobit and sample-selection models provide alternatives but have serious drawbacks. Perhaps the most pertinent in this context is conceptual: these models interpret the dependent variable as the censored observation of an underlying continuously distributed latent variable. The latent index coefficients have no predictive value for observed spending amounts. The two-part model (2PM) introduced by Cragg (1971) explicitly combines the participation and intensity effects. As discussed in Angrist (2001), researchers using this model simply pick a functional form for each part, e.g. linear probability or probit for the first part and a linear or log-linear model for the second part. This has the advantage over the Tobit and other sample-selection models is that it does not impose
} 
estimation of equation (1) for participation in any gambling suggest that the introduction of a state lottery leads to an increase in the two-week gambling participation rate. Finally, column 6 reports the estimated effect of the introduction of a state lottery on the intensity of spending. The negative coefficient on the lottery state indicator suggests that new, less-committed gamblers are being brought into the gambling sample. Estimation of a Tobit specification, which includes nongamblers in the estimation sample, corroborates the finding that gambling expenditures increase significantly in response to the presence of a state lottery.

Table 2 also displays results separately by income group, where households are divided into three strata (thirds of the income distribution) in the CEX survey data. Households in all income groups respond to a state lottery with increased gambling participation and expenditures. (Due to sample size limitations, estimating the equation separately by race is uninformative.)

\subsection{How do state lotteries affect participation in various forms of gambling?}

\section{Evidence from national gambling surveys}

The finding that household gambling expenditures rise when a state lottery is introduced suggests that lottery spending is not totally financed by a reduction in expenditures on previously existing gambling alternatives. But are they partly financed by substitution away from other gambling? To answer this question, I analyze the NORC (1998) and Kallick et. al (1975) data. Relative to the CEX Diary data, these data sources offer the advantage of recording participation by type of gambling, but they have the disadvantage of not containing expenditure amounts. The analysis of this data is thus limited to observing effects on the extensive margin of various types of gambling.

I conduct a regression-adjusted difference-in-difference (DD) analysis on the combined data to determine how the introduction of a state lottery impacts participation in various forms of gambling. The DD analysis compares the mean change in gambling participation between 1974 and 1997 among states that implement a lottery in the intervening years to the mean change in gambling participation among states that did not. The comparison group consists of the set of states that either never have a lottery or have a lottery as early as 1974 . The effect of interest is 
captured in the coefficient on LOTST7597*year1997 - the interaction between an indicator variable for the year 1997 and an indicator variable for residing in a state that adopted a lottery between 1975 and $1997 .{ }^{20}$ All regressions control for the following individual demographics: sex, race, marital status, education, and regular attendance at religious services. They also control for main year effects and a full set of state effects.

Results from the DD analysis of the effect of introducing a lottery on gambling participation are displayed in Table 3 . The introduction of a state lottery leads to a statistically significant 50.4 percentage point increase in the probability that an adult participates in gambling of any kind during the year. Not surprisingly, the introduction of a state lottery leads to an increased probability of lottery gambling. More interestingly, the introduction of a state lottery does not have a negative effect on participation in track, bingo, private, or unlicensed gambling. The estimated coefficients on the independent variable of interest - LOTST7597*year1997 - are remarkably close to zero in each of the four regressions. Again, the data reveal that adults in all income groups respond to the introduction of a state lottery with increased gambling participation. For no income group do we see a substitution away from other types of gambling.

\subsection{How do state lotteries affect household consumption?}

\section{Evidence from consumer interviews}

The analyses discussed above find no evidence that household lottery spending is financed by substitution away from previously existing forms of gambling. State lottery expenditures must therefore displace non-gambling expenditures. In this section, I analyze BLS Consumer Expenditure Survey (CEX) - Interview Survey data from 1982 to 1998 to determine to what extent household non-gambling consumption is decreased when a state lottery is introduced. The CEX Interview Survey collects information on major items of expense and household

\footnotetext{
${ }^{20}$ While a DD strategy "differences out" ex ante differences, it is still interesting to know whether such differences exist. Are there differences ex ante in gambling participation rates, conditional on individual demographics, between states in 1974 that eventually adopt a lottery and those that do not? Regression results suggest there are not. Lotst7597 is a binary indicator for whether the state implements a lottery between the two survey years. The coefficients on lotst 7597 (standard errors in parenthesis) in regressions with binary dependent variables indicating participation in the various forms of gambling are as follows: lottery .055 (.028), track .044 (.039), bingo .045 (.035), private $.105(.081)$, and unlicensed .073 (.071). These results suggest that there is no ex ante statistically significant difference in gambling participation between residents of never-lottery states and residents of states that eventually adopt lotteries.
} 
characteristics. ${ }^{21}$ Households are asked about expenditures for up to three consecutive quarters. The BLS estimates that 90 to 95 percent of expenditures are covered by the Interview survey, but gambling expenditures are excluded. The analysis therefore asks a reduced-form question: does the introduction of a state lottery lead to declines in non-gambling consumption. ${ }^{22}$

I estimate equation (1) for non-gambling consumption. Table 4 lists the results. Column 1 lists mean spending among households in states that do not have a lottery in place at the time. Column 2 reports coefficients from an OLS regression of equation (1) with spending level as the dependent variable. (All households have positive spending so composition-bias is not an issue.) Column 3 lists the implied percentage change from the non-lottery mean. The final column reports the coefficient on LOTSTATE when the dependent variable of equation (1) is the natural logarithm of expenditures. Specifying the function as log-linear has two relevant properties: one, the effect of outliers on the estimated coefficient is mitigated, and two, the coefficients are interpreted as percentage changes. This allows us to observe the proportional decline in different categories of spending.

For the overall sample, total quarterly spending falls by $\$ 115$, implying an average decrease of $\$ 38$ in monthly household consumption expenditures. The average number of adults in a CEX household is 1.57; from this we calculate an average monthly consumption reduction of $\$ 23$ per-adult. Based on the LeFleurs sales data, monthly sales per-adult average \$18 across the 38 state lotteries. We thus conclude that household lottery gambling is completely financed by a reduction in non-gambling consumption.

The decrease of $\$ 115$ in consumption expenditures represents a decline of 1.6 percent relative to mean total spending in the absence of a state lottery. The log-linear specification finds a decline of 1.9 percent (with an associated standard error of 0.7 ). This latter estimate might be preferred since the effect of outliers is mitigated. The implication is that on average, households displace two percent of their quarterly consumption expenditures with state lottery ticket purchases.

\footnotetext{
${ }^{21}$ The public use CEX Interview files do not include records from Rhode Island and Montana. Furthermore, the BLS public files suppress the state of residence for some records in order to meet the Census Disclosure Review Board's criterion that the smallest geographically identifiable area have a population of at least 100,000 . The consequence is that approximately 17 percent of records do not have state identified: state is left blank for all records from Mississippi, New Mexico, Maine, and South Dakota, and for some records from other states. The consumption analysis sample therefore includes observations from 42 states and the District of Columbia.

${ }^{22}$ The unreliability of gambling magnitudes found in the analysis of CEX Diary data preclude the construction of a two-sample IV estimate of the effect of increased gambling on non-gambling consumption.
} 
The bottom panel of Table 4 presents the results from two specification checks on the model. Recall from the discussion in Section 2.3 that the introduction of a state lottery has a nonpositive effect on the price of gambling. The magnitude of the price decrease varies by household, depending on the availability of alternative gambling forms and the associated transportation or stigma costs. The theoretical implication is that if a neighboring state already offers a state lottery, the introduction of one will have less of an effect on the price. The further implication is that the household response in terms of gambling and non-gambling consumption expenditures will be smaller.

The bottom of Table 4 reports the regression-adjusted effect of the introduction of a state lottery when a bordering state already operates one. The coefficient on the LOTSTATE indicator captures the "pure" effect of introducing a state lottery on total non-gambling consumption. The coefficient on LOTSTATE*BORDER captures the additional effect of introducing a lottery when a neighboring state already operates one. (This interaction term equals zero if the state lottery is introduced before any neighboring states introduce one; it does not switch to one if and when a neighboring state finally does introduce a state lottery.) For the overall sample, the analysis finds that households reduce quarterly consumption by $\$ 290$ when a state lottery is introduced, as shown in column 1 . If the lottery is introduced when a neighboring state already operates a lottery, the effect is mitigated by $\$ 209$, as shown in column 2 , though the point estimate is not statistically significant. Columns 3 and 4 report the coefficients from a log-linear specification. These estimates suggest that the "pure" effect of introducing a state lottery is a decline in quarterly household spending of 3.6 percent; if a border state previously operated a lottery, the decline is 1.6 percent.

An additional question is whether the shift in expenditures is temporary. The bottom panel of Table 4 confirms that the reduction in consumption is sustained in the long run. In the first two years after a state lottery is introduced, households respond with an average decline in quarterly non-gambling consumption of 1.7 percent (standard error of 0.8 ). This response is sustained: the average decline in consumption among households in states with lotteries that have been operating for at least two years, relative to households residing in states without lotteries, is 1.4 percent (standard error of 0.7 ).

\subsection{How do state lotteries effect the consumption of low-income households?}




\section{Evidence from consumer interviews}

Among households in the lowest income third, total quarterly spending is reduced by $\$ 139$ (see Table 4), implying a decrease of $\$ 46$ in monthly household consumption expenditures. (Households are divided into three strata based on the income distribution in the CEX Interview Survey sample.) Based on the average number of adults in a CEX household, we calculate a monthly consumption reduction of $\$ 29$ per-adult. How does this reduction compare to lottery ticket purchases? Sales data are not available by income group, but we can compare this decline in consumption to reported lottery gambling in the NORC (1998) survey data. Lottery-state adults in the lowest income third report an average of $\$ 139.5$ in lottery spending; adjusting this figure for known underreporting (see Section 4 above) yields average yearly spending of $\$ 162.2$, or $\$ 14$ per month. These numbers suggest that low-income households are financing their lottery gambling completely by a decline in consumption. The data suggest that lottery gambling might crowd in other gambling expenses, perhaps by reducing the "stigma" associated with gambling.

Households in the lowest income third experience the most pronounced percentage decline in consumption spending: 2.7 percent (standard error of 1.2). As reported in Table 4, OLS estimation of the log-linear specification suggests that the average response among households in the middle income group is a decline of 0.5 percent (standard error of 0.8 ); 1.4 percent (standard error of 0.8) among those in the highest income group. The data reject the hypothesis that the proportional decline for the middle income group is the same as for the lowest income group, but can not reject the hypothesis for the highest income group.

Table 5 offers a more detailed picture of how low-income households change their consumption in the presence of a state lottery. ${ }^{23}$ Equation (1) is estimated separately for 11 categories of goods: food at home; medical drugs and personal care; home - rent, mortgage, other bills; alcohol; smoking products; food out of the home; entertainment; education; household repairs, services, and furnishings; clothes (children and adult); and transportation and cars. The table reports estimates for the levels, participation, and log-linear specifications. It is difficult to obtain precise estimates in this exercise, but the analysis does offer a few interesting insights. First, the decline in consumption appears to be spread across expenditure categories. Point estimates yielded by the logarithm specification are negative for 8 of the 11

\footnotetext{
${ }^{23}$ Detailed results for the middle and highest income thirds are available from author.
} 
categories. Statistically significant reductions are observed in spending categories that might be classified as "necessities:" food at home and home expenditures including rent, mortgage, and other bills. In terms of within-household externalities, it is interesting to note that lottery spending appears to be a substitute for the "adult good" alcohol; on the other hand, there is no evidence that spending is reduced on children's clothing, but statistical power is potentially a problem.

\section{Consumer demand for lottery products}

The above section provides unambiguous evidence that households respond to the introduction of a state lottery by increasing their gambling expenditures at the expense of a reduction in other forms of consumption. If consumers are fully-rational and fully-informed, and externalities are not relevant, then these behavioral responses are consumer-welfare enhancing. However, if the oft-raised concern that consumers are making misinformed choices is true, then the effect on consumer welfare is not clear. This section provides an initial exploration of consumer choices over lottery products and investigates whether consumers of lottery products appear to make informed choices.

As outlined in the introduction, the hypothesis that lottery consumers are being deceived implies that consumer demand for lottery tickets does not respond to the expected value of a gamble, conditional on other features of the game. If consumers are misinformed, their demand for lottery gambles might respond to the top prize, but would not systematically respond to the expected value of the bet. The analysis of this section directly tests this proposition. In addition,

if consumers are risk-averse, then participation in gambles with an average return of 52 cents on the dollar reflects a fully-rational, fully-informed decision only if the participation provides some consumption, or entertainment, value. This suggests that an additional test of consumer rationality and information is whether consumers derive entertainment value from lottery gambling. To test this I investigate whether consumer demand responds to variation in nonwealth creating characteristics of lottery games, such as the number of drawings per week or the number of digits chosen. I perform these two tests simultaneously.

\subsection{Data and empirical strategy}


To investigate the nature of consumer demand, I combine game level sales data with detailed information about the corresponding lottery game. The analysis is conducted the level of state, game, and week. To the best of my knowledge, I am the first to compile a comprehensive data set of lottery game characteristics, and this is therefore the first analysis of its kind. I limit the empirical analysis to lotto games, to the exclusion of other types of lottery products including numbers games, instant scratch-off, keno, bingo, and VLT products. ${ }^{24}$ Relative to other products, lotto games vary substantially in prize amounts and structure. There is both variation across games and over time within a game as jackpot amounts frequently "rollover" and accumulate. Additionally, to draw conclusions about individual behavior from aggregate sales data I must rely on a representative agent assumption; limiting the analysis to a single type of lottery product makes this assumption substantially less stringent.

The structure of a lotto game is defined by the number of digits the bettor chooses and the size of the field. For example, in a lotto game with a 6/44 game matrix, a bettor chooses 6 numbers without replacement from a field of 44; the odds of picking the winning numbers are 1 in 7,059,052. Some lotto games have fixed jackpot amounts; others have "rolling" jackpots such that if the jackpot is not won on a given draw, the jackpot (minus the prize payments for partially correct bets) is rolled over into the jackpot for the next drawing. Some lotto games pay the jackpot as a cash prize, others as a long-term annuity, and others offer a choice. Lotto games also differ in the number of draws per week. ${ }^{25}$

\footnotetext{
${ }^{24}$ I include multi-state lotto games in the sample because the two types of products have the same essential structures; they differ only in scale. Multi-state lotto games pool sales across states to engender larger jackpots. There are six unique multi-state lotto products: Wildcard, Powerball, Cash 4 Life, and Daily Millions, which are run by the Multi-State Lottery Association; and The Big Game and Megabucks, which are not. I consider the state version of a multi-state product a unique game; for example, Powerball in Minnesota is considered a different game than Powerball in Montana. This seems appropriate as states run individual advertising campaigns.

${ }^{25}$ I offer two examples. First, a resident of Maryland playing the "Cash in Hand" game can purchase a ticket from any Maryland State Lottery location any day of the week. There are three drawings per week. He pays the retail agent $\$ 1$ and picks 7 out of 31 numbers, or marks "quick pick" and lets the machine pick the numbers for him. If the 7 numbers on his gameboard match the 7 winning numbers (with odds of 1:2,629,575), and he claims his prize within 182 days from the date of drawing, he is paid $\$ 500,000$ cash. The state of Maryland will pay each game board with the winning numbers $\$ 500,000$. (In the unlikely event that more than 5 game boards win, all winning boards will receive an equal share of a $\$ 2,500,000$ pool.) Second, a resident of Florida playing Florida Lotto pays $\$ 1$ and picks 6 numbers out of 53, or marks "quick pick". She can place bets on up to 26 consecutive drawings in advance. If the 6 numbers on her ticket match the 6 winning numbers (with odds of 1:22,957,480), and she claims her prize within 180 days, she wins the jackpot amount. The actual prize depends on sales and the number of winners for the draw. If there is no ticket with the winning number, the jackpot rolls over and the cash available for that jackpot is added to the next jackpot prize pool.
} 
I obtained weekly sales data from 1992 to 1999 from Lefleurs Inc., a group that collects weekly sales data from state lottery agencies. (Appendix Table 2 describes the sales data.) I obtained information about game characteristics from state lottery websites and from lottery game brochures provided by state lottery agencies. For games with rolling jackpots, I obtained times series data on the advertised jackpot amounts from various state lottery agencies. The sample excludes games for which only realized jackpot data is available; in games in which the jackpot rolls over, the actual jackpot amount is a function of both the rollover amount and the induced additional sales. Using the advertised amount avoids incorporating this latter portion into the independent variable. For state-game-week cells that have more than one advertised jackpot (because there are multiple drawings per week and the jackpot is not a fixed amount), I take the maximum advertised jackpot during the week. The final sample used in the empirical analysis consists of nearly 15,000 observations at the game-week level. These observations are from a sample of 91 lotto products from 33 states.

The empirical analysis estimates how weekly sales of lotto tickets respond to changes in the statistical moments of the gamble as well as to differences in game characteristics. The estimating equation takes the following form:

$$
\begin{aligned}
& y_{\mathrm{sgw}}=\alpha+\lambda_{1}(\text { expected value })_{\mathrm{sgw}}+\lambda_{2}\left(\text { variance }_{\mathrm{sgw}}+\lambda_{3}(\text { skewness })_{\mathrm{sgw}}+\right. \\
& +\lambda_{5}(\text { nominal top prize })_{\mathrm{sgw}}+\mathrm{X}_{\mathrm{sgw}} \beta_{1}+\mathrm{Z}_{\mathrm{sy}} \beta_{2}+\zeta_{\mathrm{s}}+\omega_{\mathrm{w}}+v_{\mathrm{g}}+\varepsilon_{\mathrm{ijt}} \text {. }
\end{aligned}
$$

where $y_{\mathrm{sgw}}$ is the natural logarithm of per adult sales from game $g$, in state $s$, in week $w$. (A loglinear specification is used in order to generate estimates of percentage changes in sales, rather than changes in levels. In addition, the logarithmic transformation removes the heteroskedasticity in the residuals of sales.) The vector $\mathrm{X}_{\mathrm{sgw}}$ includes non-wealth creating characteristics of the game. The vector $Z_{\text {sy }}$ includes controls for the proportion of the state population in seven age-sex demographic groups, observed at the year level. All regressions control for state and week effects, $\zeta_{\mathrm{s}}+\omega_{\mathrm{w}}$. In some specifications, the equation is estimated with a game dummy $v_{\mathrm{g}}$ to control for unobserved product fixed effects. The equation is estimated using OLS, weighted by state population. Standard errors are robust standard errors, adjusted for clustering at the stateyear level to flexibly control for correlation of the error terms.

The moments of a one dollar gamble depend on several factors: the structure of the game, the value of previous rolled-over jackpots, and the number of tickets bought in the current drawing. The moments are calculated using the "real top prize," which is the present discounted 
value of the advertised jackpot (assuming a six percent interest rate), and all lower prize tiers offered by a game. All prize amounts are adjusted to year 2000 dollars. I make the simplifying assumption that the probability of multiple winners, which depends on the number of tickets bought and the numbers chosen by bettors, is negligible. Hence, the expected value is not adjusted for the probability of having to share the jackpot. The mean expected value of a $\$ 1$ bet among the sample of all lotto games is 0.53 .

The "nominal top prize" of a game is the advertised dollar amount. This is the undiscounted sum of the game-specific number of annual payments. In the analysis, the "nominal top prize" is adjusted to year 2000 dollars using the Consumer Price Index, but it is not discounted to present terms. In most instances, it is nearly twice as large as the "real top prize." The highest single-state lotto prize in the sample is associated with the Texas Lotto in January, 1994: a nominal top prize of $\$ 18$ million, with a present discounted value of $\$ 10$ million. The largest prize among multi-state games is associated with the Powerball game in July 1998; the nominal prize amount is $\$ 266$ million, with a present discounted value of $\$ 147$ million. (The actual jackpot won on this game was $\$ 295.7$ million, in year 2000 dollars.) The vector $\mathrm{X}_{\mathrm{sgw}}$ includes the following non-wealth creating game characteristics: number of draws per week, age of game, age of game squared, how many numbers the bettor picks, and the jackpot type (cash, annuity, or a choice).

\subsection{Results}

Table 6 displays the estimation results. All regressions control for state unemployment rate, state fixed effects, week fixed effects, and state demographic composition. Column 1 displays the results of estimating demand as a function of only the statistical moments of the gamble. The results provide preliminary evidence that consumers respond positively to the expected value of a gamble, but the point estimate is not statistically significant. This specification suggests that consumers like variance, but dislike skewness. Note that this finding contradicts the finding of Garrett and Sobel (1999) that consumers respond negatively to variance and positively to skewness. ${ }^{26}$ Column 2 adds entertainment characteristics as independent variables. The positive

\footnotetext{
${ }^{26}$ A rigorous analysis of consumer preferences for risk requires more structure than the analysis presented here; such an analysis using this data is provided in Kearney 2002.
} 
coefficient on expected value increases in absolute value to 0.683 and is statistically significant (standard error of 0.113 ). This finding rejects the hypothesis that lottery players are misinformed evaluators of gambles.

Column 2 shows that consumer purchases are also driven by non-wealth creating characteristics of lottery products. This implies that consumers are deriving entertainment value from playing the lottery. For example, consumers appear to prefer picking more numbers to fewer and demand more of a game as it ages. The specification reported in column 3 adds the nominal top prize as an independent variable. Not surprisingly, it enters positively and is statistically significant. The interesting result in this column is that the estimated positive effect of expected value is maintained and even strengthened. The point estimate is 0.757 , with a standard error of 0.108 . Replacing "expected value" with the natural logarithm of one minus the expected value in this specification, yields an estimated price elasticity of -0.39 .

The specifications reported in columns 4 and 5 incorporate product fixed effects into the model. The estimation now controls for differences in sales across games that are driven by fixed game characteristics not explicitly captured by the regressors in the model. Again, the data demonstrate that sales are positively driven by the expected value of a gamble and that demand responds to the non-wealth creating characteristics of lotto games. The specification in column 5 yields an estimated price elasticity of -0.17 .

It is consistent with these findings to claim that consumers are fully rational: they derive an entertainment value from participating in the lotto gamble that equals the price of the gamble (one minus expected value), and then, insofar as they are making investments, they recognize which gambles are better investments. On the other hand, it is also consistent to argue that consumers are at least partially irrational, believing that the non-wealth characteristics bear on the likelihood of winning positive returns. Though the analysis does not allow us to discriminate between the two scenarios, it does imply that consumers are at least partly - and potentially fully - informed in recognizing the wealth value of a bet.

\section{Conclusion}

This paper has offered two main contributions to the public debate regarding the consumer consequences of state lotteries. The first contribution is an empirical investigation of how 
households shift their spending in response to the introduction of a state lottery. I have used the variation across states in the timing of state lottery introduction to compare the change in expenditures among households in states that implement lotteries to the change in expenditures among households in states that do not. The analyses are based on consumer expenditure data from 1982 to 1998, during which time 21 states implemented lotteries.

The evidence on household gambling expenditures demonstrates that households increase their gambling expenditures in the presence of a state lottery. Total gambling after a lottery is introduced exceeds previous gambling expenditures, which implies that households are not financing lottery gambling completely by substituting away from other forms of gambling. A complementary analysis of participation in various forms of gambling finds that there is no substitution away from participation in other forms of gambling when a lottery is introduced. In fact, my analysis of household non-gambling consumption suggests that household spending on lottery tickets is financed completely by a reduction in other forms of household consumption. The introduction of a state lottery is associated with a decline in household non-gambling consumption of $\$ 115$ per quarter. This figure implies a monthly reduction of $\$ 23$ in per-adult consumption, which compares to average monthly sales of $\$ 18$ per lottery-state adult. The response is most pronounced for low-income households, which on average reduce nongambling expenditures by approximately three percent. The impact of a state lottery is found to be more pronounced if no bordering state previously implemented a lottery. In addition, the decline in non-gambling consumption is sustained in the long run.

The second major contribution of the paper is an evaluation of whether lottery consumers appear to be making informed choices. To evaluate this question I analyze lottery sales data from 91 lotto games from 1992 to 1998 as a function of lottery product attributes, including the statistical moments of the gamble, the advertised undiscounted top prize, and the non-wealth creating characteristics of the game. The analysis suggests that sales are positively driven by the expected value of a gamble, controlling for other characteristics. This finding is robust to alternative specifications, including controlling for unobserved product fixed effects. The NORC (1998) survey offers supporting evidence that agents understand that state lotteries do not offer fair bets. The survey asks respondents how much of the ticket price of their favorite game do they think is returned as prize money. Only 7.5 percent of the respondents thought the pay-out 
was above the actual average pay-out rate. This finding suggests that consumers are at least partly - and potentially fully - informed in recognizing the wealth value of a bet.

Two things should be kept in mind when interpreting the results of this paper. First, the analysis has identified average effects, but due to data limitations, can not sufficiently examine the heterogeneity of household response. While the average household reduces consumption by $\$ 38$ a month in response to the introduction of a state lottery, there are likely to be some households in the tail of the distribution who forego much greater amounts of consumption. Second, intra-household externalities are a potential issue that can not be sufficiently addressed with available data. For example, there is some anecdotal evidence to suggest that some members of lottery-gambling households would rather not spend household money on lottery tickets. Future work examining these issues would lead to a more thorough understanding of the welfare implications of state lotteries. 


\section{References}

Ali, M.M. 1977. "Probability and utility estimates for racetrack bettors." Journal of Political Economy 85, 803-815.

Angrist, J. 2001. "Estimation of Limited Dependent Variable Models With Dummy Endogenous Regressors: Simple Strategies for Empirical Practice.” Journal of Business and Economic Statistics, 19, No. 1.

Becker, G. and K. Murphy. 1988. “A Theory of Rational Addiction,” Journal of Political Economy.

Berry, F.S. and W.D. Berry. 1990. "State Lottery Adoptions as Policy Innovations: An Event History Analysis," American Political Science Review, 84(2).

Browning, M. and P. Chiappori. 1998. "Efficient Intra-Household Allocations: A General Characterization.” Econometrica, 66(6), 1241-1278.

Cragg, J.G. 1971. "Some Statistical Models for Limited Dependent Variables With Application to the Demand for Durable Goods," Econometrica, 39, 829-844.

Clotfelter, C.T., P.J. Cook, J.A. Edell, and M. Moore. 1999. State Lotteries at the Turn of the Century: Report to the National Gambling Impact Study Commission. Duke University.

Clotfelter, C.T. and P.J. Cook. 1990a. "On the Economics of State Lotteries," The Journal of Economic Perspectives, 4(4), 105-119.

- 1990b. "Redefining Success in the State Lottery Business," Journal of Policy Analysis and Management 9.

- 1989. Selling Hope: State Lotteries in America. Cambridge, MA: Harvard University Press.

Duflo, E. 2000. "Grandmothers and Granddaughters: The Effects of Old Age Pension on Child Health in South Africa." MIT Department of Economics working paper.

Forrest, D.O., D. Gulley, and R. Simmons. 2000. "Elasticity of Demand for UK National Lottery Tickets," National Tax Journal 53(4), 853-863.

Friedman, M., and L.J. Savage. 1948. “The Utility Analysis of Choices Involving Risk.” Journal of Political Economy 56, 279-304.

Garrett, T.A. and R.S. Sobel. 1999. "Gamblers favor skewness, not risk: Further evidence from United States' lottery games.” Economic Letters 63, 85-90. 
Geary, R. 1997. “The Numbers Game: State lotteries - A Ticket to Poverty," in The New Republic, May 19.

Gerstein, D. and M. Toce. 1999. Fast Track Codebook for the Gambling Impact and Behavior Study-Adult Surveys. National Opinion Research Council.

Golec, J., and M. Tamarkin. 1998. Bettors love skewness, not risk, at the horse track. Journal of Political Economy 56, 279-304.

Gruber, J. and B. Koszegi. 2000. "Is Addiction 'Rational'? Theory and Evidence.” NBER Working Paper No. W7507.

Gtech Corporation. 2000. The Vital Signs of Legalized Gaming in America: Gtech's 8th Annual National Gaming Survey. West Greenwich, RI.

Gulley, O. D., and F. A. Scott. 1993. "The Demand for Wagering on State-Operated Lotto Games," National Tax Journal, 45(1): 13-22.

Imbens, G.W., D.B. Rubin, and B. Sacerdote. 1999. "Estimating the Effects of Unearned Income on Labor Supply, Earnings, Savings, and Consumption: Evidence from a Survey of Lottery Players." NBER Working Paper No. W7001.

International Gaming \& Wagering Business, April 1998, 44;

International Gaming \& Wagering Business, June 1998, 48-49.

Kahneman, D., and A. Tversky. 1979. Prospect theory: An analysis of decision under risk. Econometrica 47, 263-291.

Kallick, M., D. Suits, T. Dielman, and J. Hybels. 1976. Gambling in The United States (ICPSR 7495) University of Michigan Institute for Social Research.

Kearney, M.S. 2001. "State Lotteries and Consumer Behavior." MIT Department of Economics, unpublished mimeo, November.

Kearney, M.S. 2002. "Preferences under Risk: The Case of State Lottery Bettors.” In unpublished MIT Ph.D. dissertation.

Spindler, C.J. 1995. "The Lottery and Education: Robbing Peter to Pay Paul?" Public Budgeting and Finance, 15, 54-62.

LaFleur's World Lottery Almanac. 2001. LaFleur's Inc. www.lafleurs.com. 
Mullahy, J. 1997. "Instrumental-Variable Estimation of Count Data Models: Applications to Models of Cigarette Smoking Behaviour," Review of Economics and Statistics, 11, 586593.

National Gambling Impact Study Commission. 1999. Final Report.

National Public Radio, All Things Considered, April 14, 1999.

National Public Radio, All Things Considered, June 22, 1999.

Pulley, B. 1999. "Waiting for riches: a special report - living off the daily dream of winning a lottery prize," The New York Times, May 22, A1.

Thaler, R.H. and W.T. Ziemba. 1988. “Anomalies. Parimutuel betting markets: Racetracks and lotteries. Journal of Economic Perspectives 2(2), 161-174.

Udry, C. 1996. "Gender, Agricultural Production, and the Theory of the Household," Journal of Political Economy, 101 (5), 1010-1045.

United States Department of Labor, Bureau of Labor Statistics. 2001. "Consumer Expenditures in 1999." Report 949.

Worthington, A. 2001. "Implicit Finance in Gambling Expenditures: Australian Evidence on Socioeconomic and Demographic Tax Incidence," Public Finance Review, 29 (4), 326342. 


\begin{tabular}{|c|c|c|c|c|c|c|c|c|c|}
\hline \multicolumn{10}{|c|}{$\begin{array}{c}\text { Table } 1 \\
\text { Lottery Participation Rates and Expenditures } \\
1998 \text { NORC Survey Data } \\
\end{array}$} \\
\hline & \multicolumn{3}{|c|}{ Overall } & \multicolumn{3}{|c|}{ Lottery States } & \multicolumn{3}{|c|}{ Non-lottery states } \\
\hline & $n$ & $\begin{array}{l}\text { \% who } \\
\text { played } \\
\text { last year }\end{array}$ & $\begin{array}{c}\text { Mean } \\
\text { annual } \\
\text { spending, } \\
\text { all adults } \\
\end{array}$ & $n$ & $\begin{array}{l}\% \text { who } \\
\text { played } \\
\text { last year }\end{array}$ & $\begin{array}{c}\text { Mean } \\
\text { annual } \\
\text { spending, } \\
\text { all adults } \\
\end{array}$ & $n$ & $\begin{array}{c}\% \text { who } \\
\text { played } \\
\text { last } \\
\text { year }\end{array}$ & $\begin{array}{c}\text { Mean } \\
\text { annual } \\
\text { spending, } \\
\text { all adults }\end{array}$ \\
\hline overall & 2,417 & 51.3 & $\begin{array}{c}107.3 \\
(470.7)\end{array}$ & 2,047 & 55.7 & 128.4 & 357 & 25.2 & $\begin{array}{c}47.3 \\
(240.9)\end{array}$ \\
\hline male & 1,152 & 55.8 & $\begin{array}{c}143.2 \\
(525.7)\end{array}$ & 981 & 51.8 & 153.4 & 163 & 30.1 & $\begin{array}{c}82.5 \\
(331.1)\end{array}$ \\
\hline female & 1,265 & 47.2 & $\begin{array}{c}91.8 \\
(494.6)\end{array}$ & 1,066 & 59.9 & 105.3 & 194 & 21.1 & $\begin{array}{c}17.8 \\
(114.7)\end{array}$ \\
\hline white & 1,769 & 52.4 & $\begin{array}{c}107.9 \\
(510.0)\end{array}$ & 1,059 & 57.0 & $\begin{array}{c}119.3 \\
(544.3)\end{array}$ & 251 & 24.3 & $\begin{array}{c}41.4 \\
(215.8)\end{array}$ \\
\hline black & 291 & 42.3 & $\begin{array}{c}200.1 \\
(711.9)\end{array}$ & 237 & 46.0 & $\begin{array}{c}230.0 \\
(770.5)\end{array}$ & 53 & 24.5 & $\begin{array}{c}67.0 \\
(333.8)\end{array}$ \\
\hline hispanic & 170 & 58.8 & $\begin{array}{c}108.4 \\
(214.9)\end{array}$ & 154 & 61.0 & $\begin{array}{c}107.5 \\
(208.0)\end{array}$ & 14 & 28.6 & $\begin{array}{c}86.7 \\
(288.0)\end{array}$ \\
\hline other & 180 & 47.2 & $\begin{array}{c}74.9 \\
(257.3)\end{array}$ & 141 & 51.8 & $\begin{array}{c}81.8 \\
(263.1)\end{array}$ & 38 & 28.9 & $\begin{array}{c}45.5 \\
(238.1)\end{array}$ \\
\hline \multicolumn{10}{|l|}{ Household income } \\
\hline$<27,000$ & 353 & 45.0 & $\begin{array}{c}125.4 \\
(560.5)\end{array}$ & 287 & 50.5 & $\begin{array}{c}139.5 \\
(610.0)\end{array}$ & 63 & 17.5 & $\begin{array}{c}53.0 \\
(245.5)\end{array}$ \\
\hline 27,000 to 54,000 & 445 & 56.2 & $\begin{array}{c}113.4 \\
(455.0)\end{array}$ & 368 & 63.0 & $\begin{array}{c}127.1 \\
(485.2)\end{array}$ & 76 & 22.4 & $\begin{array}{c}48.0 \\
(261.0)\end{array}$ \\
\hline$>54,000$ & 635 & 59.5 & $\begin{array}{c}145.8 \\
(554.3)\end{array}$ & 550 & 62.9 & $\begin{array}{c}158.9 \\
(584.1)\end{array}$ & 83 & 36.1 & $\begin{array}{c}59.9 \\
(286.8)\end{array}$ \\
\hline hs drop out & 326 & 46.3 & $\begin{array}{c}170.2 \\
(716.4)\end{array}$ & 257 & 54.0 & $\begin{array}{c}197.2 \\
(794.0)\end{array}$ & 65 & 13.8 & $\begin{array}{c}63.9 \\
(261.4)\end{array}$ \\
\hline hs graduate & 613 & 52.4 & $\begin{array}{c}137.5 \\
(573.8)\end{array}$ & 527 & 57.3 & $\begin{array}{c}155.1 \\
(613.2)\end{array}$ & 82 & 19.5 & $\begin{array}{c}28.8 \\
(175.2)\end{array}$ \\
\hline some college & 736 & 55.6 & $\begin{array}{c}109.1 \\
(504.0)\end{array}$ & 624 & 58.8 & $\begin{array}{c}120.0 \\
(538.2)\end{array}$ & 110 & 36.4 & $\begin{array}{c}47.3 \\
(231.3)\end{array}$ \\
\hline college grad & 742 & 48.4 & $\begin{array}{c}82.2 \\
(310.6) \\
\end{array}$ & 639 & 52.0 & $\begin{array}{c}86.7 \\
(315.3) \\
\end{array}$ & 100 & .25 & $\begin{array}{c}51.8 \\
(283.0) \\
\end{array}$ \\
\hline \multicolumn{10}{|c|}{$\begin{array}{l}\text { notes: } \\
\text { 1. Data is from the } 1998 \text { National Survey on Gambling conducted by the National Opinion Research Council (NORC) } \\
\text { under contract with the National Gambling Impact Study Commission. These estimates of annual lottery expenditures } \\
\text { incorporate a set of assumptions used by Clotfelter and Cook (1999), as described in the text. The data is not adjusted } \\
\text { for the underreporting of lottery sales documented by Clotfelter and Cook (1999). } \\
\text { 2. All expenditure amounts are adjusted to year } 2000 \text { dollars using the Consumer Price Index. } \\
\text { 3. Standard errors in parenthesis. }\end{array}$} \\
\hline
\end{tabular}


Table 2

Effects of a State Lottery on Two-week Gambling Participation Rate and Expenditures:

Coefficient on LOTSTATE

CEX Diary Data

\begin{tabular}{|c|c|c|c|c|c|c|c|c|c|c|}
\hline & (1) & (2) & & (3) & (4) & & (5) & & (6) & \\
\hline & $\begin{array}{c}\text { Mean } \\
\text { expenses } \\
\text { (no } \\
\text { lottery) }\end{array}$ & $\begin{array}{l}\text { OLS } \\
\text { Level }\end{array}$ & & $\begin{array}{c}\text { Mean } \\
\text { participation } \\
\text { (no lottery) }\end{array}$ & $\begin{array}{l}\text { OLS } \\
\text { Any }\end{array}$ & & $\begin{array}{c}\text { Probit } \\
\text { Any }\end{array}$ & & $\begin{array}{l}\text { OLS } \\
\text { Ln }\end{array}$ & \\
\hline $\begin{array}{l}\text { Overall } \\
(n=79,064)\end{array}$ & $\begin{array}{c}.714 \\
(10.3)\end{array}$ & $\begin{array}{l}1.43 \\
(.353)\end{array}$ & $* * *$ & $\begin{array}{c}.019 \\
(.136)\end{array}$ & $\begin{array}{l}.069 \\
(.006)\end{array}$ & $* * *$ & $\begin{array}{l}.061 \\
(.004)\end{array}$ & $* * *$ & $\begin{array}{l}-.282 \\
(.089)\end{array}$ & $* * *$ \\
\hline $\begin{array}{l}\text { Lowest income } \\
(n=25,538)\end{array}$ & $\begin{array}{c}.487 \\
(8.67)\end{array}$ & $\begin{array}{l}.438 \\
(.242)\end{array}$ & & $\begin{array}{c}.011 \\
(.106)\end{array}$ & $\begin{array}{l}.032 \\
(.005)\end{array}$ & $* * *$ & $\begin{array}{l}.035 \\
(.003)\end{array}$ & $* * *$ & $\begin{array}{l}-.395 \\
(.186)\end{array}$ & $* *$ \\
\hline $\begin{array}{l}\text { Middle income } \\
(n=27,394)\end{array}$ & $\begin{array}{c}.561 \\
(6.94)\end{array}$ & $\begin{array}{c}1.32 \\
(.309)\end{array}$ & $* * *$ & $\begin{array}{c}.019 \\
(.136)\end{array}$ & $\begin{array}{c}.069 \\
(.007)\end{array}$ & $* * *$ & $\begin{array}{c}.070 \\
(.003)\end{array}$ & $* * *$ & $\begin{array}{l}-.207 \\
(.156)\end{array}$ & \\
\hline $\begin{array}{l}\text { Highest income } \\
(n=26,132)\end{array}$ & $\begin{array}{c}1.12 \\
(14.3)\end{array}$ & $\begin{array}{l}2.45 \\
(.863)\end{array}$ & $* * *$ & $\begin{array}{l}.027 \\
(.161)\end{array}$ & $\begin{array}{l}.102 \\
(.009)\end{array}$ & $* * *$ & $\begin{array}{l}.109 \\
(.004)\end{array}$ & $* * *$ & $\begin{array}{l}-.308 \\
(.131)\end{array}$ & $* *$ \\
\hline
\end{tabular}

notes:

1. Data are from confidential Bureau of Labor Statistics (BLS) Consumer Expenditure Survey (CEX) - Diary Survey data files from 1984 to 1999. Data are not adjusted for the underreporting of lottery expenditures described in the text. All dollar values are adjusted to year 2000 dollars using the BLS Consumer Price Index.

2. The LOTSTATE indicator is equal to one if there is a state lottery in the household's state of residency during the two-week reference period.

3. Standard errors are White's robust standard errors adjusted for clustering within a state-year cell.

4. $* * *$ indicates significance at 99 percentile $* *$ at 95 percentile

5. A Tobit specification for levels suggests the same patterns. The coefficients are as follows: overall 58.2; lowest income 31.7; middle income 46.0; highest income 72.9 .

6. All regressions include controls for the following household demographics: family size, before-tax income, urban status, number of persons less than 18 and over 64, the sex and educational attainment of the household head, the race of the household head (when it is not the conditioning variable). All regressions also include controls for state, year, month of year, and state cigarette, beer, and gasoline tax levels. 


\section{Table 3}

\section{Effects of a State Lottery on Gambling Participation: Difference-in-Difference Estimates}

\begin{tabular}{|c|c|c|c|c|c|c|c|c|}
\hline Dep Variable & any & & lottery & & track & bingo & private & unlicensed \\
\hline $\begin{array}{l}\text { Overall } \\
(n=2,572)\end{array}$ & $\begin{array}{l}.504 \\
(.117)\end{array}$ & $* * *$ & $\begin{array}{l}.429 \\
(.036)\end{array}$ & $* * *$ & $\begin{array}{l}.011 \\
(.027)\end{array}$ & $\begin{array}{l}-.002 \\
(.027)\end{array}$ & $\begin{array}{l}.009 \\
(.034)\end{array}$ & $\begin{array}{l}-.023 \\
(.033)\end{array}$ \\
\hline $\begin{array}{l}\text { Lowest income } \\
(n=629)\end{array}$ & $\begin{array}{l}.526 \\
(.217)\end{array}$ & $* *$ & $\begin{array}{l}.448 \\
(.072)\end{array}$ & $* * *$ & $\begin{array}{l}-.008 \\
(.045)\end{array}$ & $\begin{array}{l}-.003 \\
(.053)\end{array}$ & $\begin{array}{l}.057 \\
(.071)\end{array}$ & $\begin{array}{l}-.031 \\
(.056)\end{array}$ \\
\hline $\begin{array}{l}\text { Middle income } \\
(n=991)\end{array}$ & $\begin{array}{l}.836 \\
(.203)\end{array}$ & $* * *$ & $\begin{array}{l}.469 \\
(.063)\end{array}$ & $* * *$ & $\begin{array}{l}.053 \\
(.043)\end{array}$ & $\begin{array}{l}.064 \\
(.045)\end{array}$ & $\begin{array}{l}.065 \\
(.054)\end{array}$ & $\begin{array}{l}.002 \\
(.055)\end{array}$ \\
\hline $\begin{array}{l}\text { Highest income } \\
(n=952)\end{array}$ & $\begin{array}{l}.413 \\
(.230)\end{array}$ & $*$ & $\begin{array}{l}.392 \\
(.066)\end{array}$ & $* * *$ & $\begin{array}{l}-.001 \\
(.059)\end{array}$ & $\begin{array}{l}-.091 \\
(.052)\end{array}$ & $\begin{array}{l}-.056 \\
(.060)\end{array}$ & $\begin{array}{l}-.049 \\
(.066)\end{array}$ \\
\hline
\end{tabular}

notes:

1. Data on participation in the five types of gambling are from the 1975 National Survey of Adult Gambling conducted by Kallick et al. at the University of Michigan and the 1998 National Survey on Gambling conducted by the National Opinion Research Council (NORC) under contract with the National Gambling Impact Study Commission. The Kallick et. al. (1975) data consist of 1,749 completed interviews covering participants' lifetime and past-year gambling behavior. The NORC (1998) data contain information about the gambling behavior of 2,417 adults from a random-digit dial sample.

2. The reported difference-in-difference estimate is the coefficient on LOTST7597*year1997 — the interaction between an indicator variable for the year 1997 and an indicator variable for residing in a state that adopted a lottery between 1975 and 1997.

3. All regressions control for sex, race, marital status, education, and regular attendance at religious services. They also control for main year and state effects.

4. Standard errors are White's robust standard errors adjusted for clustering within a state-year cell.

5. *** indicates significance at 99 percentile ** at 95 percentile

6. "Any" gambling is not equal to the sum of the five types of gambling displayed because the 1998 file separately categorizes participation in casino, charitable, card, bar/restaurant, internet, and indian reservation gambling. 


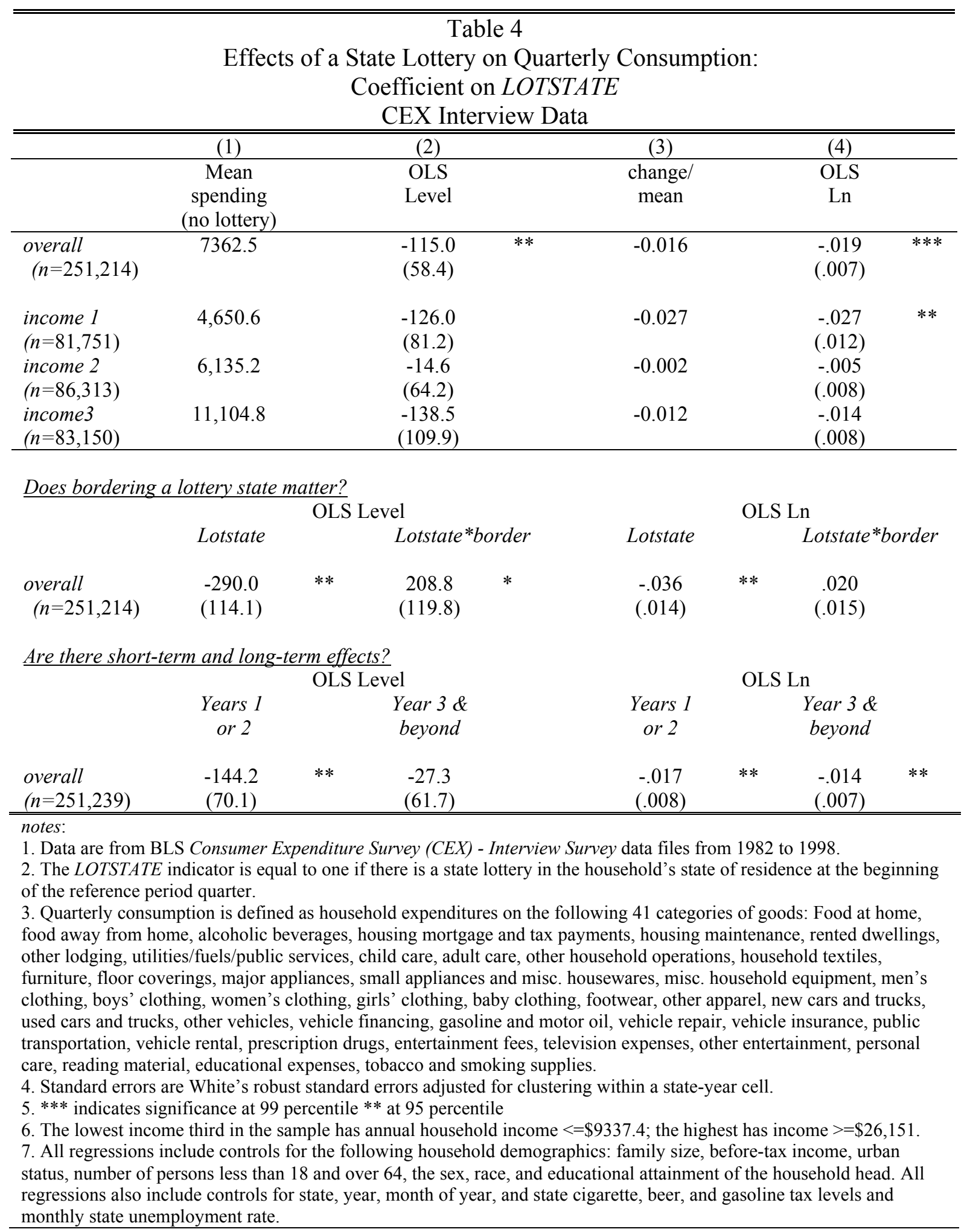




\begin{tabular}{|c|c|c|c|c|c|c|c|}
\hline \multicolumn{8}{|c|}{$\begin{array}{l}\text { Effects of a State Lottery on Quarterly Consumption: } \\
\text { Coefficient on LOTSTATE, by Expenditure Category } \\
\text { CEX Interview Data - Households in the Lowest Income Third }\end{array}$} \\
\hline & $\begin{array}{c}\text { Mean } \\
\text { spending } \\
\text { (no lottery) }\end{array}$ & $\begin{array}{l}\text { OLS } \\
\text { Level }\end{array}$ & & $\begin{array}{l}\text { OLS } \\
\text { Any }\end{array}$ & & $\begin{array}{c}\text { OLS } \\
\text { Ln } \\
\text { (c.o.p.) }\end{array}$ & \\
\hline total spending & $4,650.6$ & $\begin{array}{l}-126.0 \\
(81.2)\end{array}$ & & - & & $\begin{array}{l}-.027 \\
(.012)\end{array}$ & $* *$ \\
\hline 1. food at home & 750.9 & $\begin{array}{l}-12.9 \\
(10.3)\end{array}$ & & $\begin{array}{l}-.004 \\
(.002)\end{array}$ & & $\begin{array}{l}-.031 \\
(.016)\end{array}$ & $* *$ \\
\hline $\begin{array}{l}\text { 2. medical drugs and } \\
\text { personal care }\end{array}$ & 119.5 & $\begin{array}{l}1.16 \\
(3.74)\end{array}$ & & $\begin{array}{l}.0005 \\
(.009)\end{array}$ & & $\begin{array}{l}.006 \\
(.019)\end{array}$ & \\
\hline $\begin{array}{l}\text { 3. home - mortgage, rent, } \\
\text { other bills }\end{array}$ & $1,427.7$ & $\begin{array}{l}-84.5 \\
(30.8)\end{array}$ & $* * *$ & $\begin{array}{l}-.002 \\
(.002)\end{array}$ & & $\begin{array}{l}-.069 \\
(.021)\end{array}$ & $* * *$ \\
\hline 4. alcohol & 64.9 & $\begin{array}{l}-6.33 \\
(2.66)\end{array}$ & $* *$ & $\begin{array}{l}-.022 \\
(.009)\end{array}$ & $* *$ & $\begin{array}{l}-.048 \\
(.028)\end{array}$ & \\
\hline 5. smoking & 64.6 & $\begin{array}{l}-2.94 \\
(2.21)\end{array}$ & & $\begin{array}{l}-.014 \\
(.008)\end{array}$ & & $\begin{array}{l}-.009 \\
(.022)\end{array}$ & \\
\hline 6. food out & 248.3 & $\begin{array}{l}-9.96 \\
(9.07)\end{array}$ & & $\begin{array}{l}-.002 \\
(.008)\end{array}$ & & $\begin{array}{l}-.034 \\
(.024)\end{array}$ & \\
\hline 7. entertainment & 249.4 & $\begin{array}{c}3.98 \\
(16.3)\end{array}$ & & $\begin{array}{l}.008 \\
(.009)\end{array}$ & & $\begin{array}{l}-.025 \\
(.026)\end{array}$ & \\
\hline 8. education & 119.1 & $\begin{array}{c}3.01 \\
(11.3)\end{array}$ & & $\begin{array}{l}.007 \\
(.008)\end{array}$ & & $\begin{array}{l}.037 \\
(.067)\end{array}$ & \\
\hline $\begin{array}{l}\text { 9. house - repairs, } \\
\text { services, furnishings }\end{array}$ & 373.9 & $\begin{array}{l}-8.94 \\
(19.3)\end{array}$ & & $\begin{array}{l}.001 \\
(.009)\end{array}$ & & $\begin{array}{l}-.052 \\
(.033)\end{array}$ & \\
\hline 10. clothes & 264.2 & $\begin{array}{l}-10.8 \\
(9.02)\end{array}$ & & $\begin{array}{l}-.010 \\
(.008)\end{array}$ & & $\begin{array}{l}-.020 \\
(.026)\end{array}$ & \\
\hline 10a. kids & 39.9 & $\begin{array}{l}-.664 \\
(2.00)\end{array}$ & & $\begin{array}{l}-.0004 \\
(.006)\end{array}$ & & $\begin{array}{l}-.006 \\
(.034)\end{array}$ & \\
\hline 10b. adult & 224.2 & $\begin{array}{l}-10.1 \\
(7.93)\end{array}$ & & $\begin{array}{l}-.009 \\
(.008)\end{array}$ & & $\begin{array}{l}-.024 \\
(.026)\end{array}$ & \\
\hline 11. transportation/cars & 968.1 & $\begin{array}{c}2.29 \\
(39.8)\end{array}$ & & $\begin{array}{l}-.009 \\
(.007)\end{array}$ & & $\begin{array}{l}.030 \\
(.025)\end{array}$ & \\
\hline sample size & & 81,751 & & & & & \\
\hline $\begin{array}{l}\text { notes: } \\
\text { 1. Data are from BLS Consun } \\
\text { 2. The LOTSTATE indicator } \\
\text { reference period quarter. } \\
\text { 3. Category } 3 \text { includes expend } \\
\text { Category } 7 \text { includes expendit } \\
\text { expenditures on housing main } \\
\text { major appliances, small applia } \\
\text { cars and trucks, used cars and } \\
\text { transportation, and vehicle rer } \\
\text { 4. Standard errors are White's } \\
\text { 5. *** indicates significance a } \\
\text { 6. The lowest income third in } \\
\text { 7. All regressions include con } \\
\text { persons less than } 18 \text { and over } \\
\text { for state, year, month of year, }\end{array}$ & $\begin{array}{l}\text { Expenditure } S \\
\text { qual to one if th } \\
\text { res on mortgas } \\
\text { on entertainm } \\
\text { ance, child car } \\
\text { es and misc. ho } \\
\text { cks, other vehi } \\
\text { s. } \\
\text { bust standard e } \\
9 \text { percentile ** } \\
\text { sample distrib } \\
\text { ls for the follov } \\
\text { the sex, race, } \\
\text { d state cigarett }\end{array}$ & $\begin{array}{l}\text { Interview } \\
\text { lottery in } \\
\text { iments, re } \\
\text { vision exp } \\
\text { other hou } \\
\text { d misc. ho } \\
\text { financing, } \\
\text { for cluste } \\
\text { tile } \\
\text { acterized b } \\
\text { ld demogr } \\
\text { alal attainm } \\
\text { asoline tax }\end{array}$ & $\begin{array}{l}\text { urvey } \\
\text { house } \\
\text { d dwel } \\
\text { ses, oth } \\
\text { hold op } \\
\text { ehold } \\
\text { asoline } \\
\text { ng with } \\
\text { annual } \\
\text { hics: fo } \\
\text { t of th }\end{array}$ & $\begin{array}{l}\text { illes from } \\
\text { 's state o } \\
\text {, other lo } \\
\text { ntertainm } \\
\text { ons, hous } \\
\text { ment. Ca } \\
\text { motor oil } \\
\text { state-yea } \\
\text { ehold in } \\
\text { size, be } \\
\text { isehold h } \\
\text { onthly st }\end{array}$ & $\begin{array}{l}\text { ld te } \\
\text { ory } 1 \\
\text { hicle } \\
\text { ll. } \\
\text {-tax } \\
\text {-tax }\end{array}$ & $\begin{array}{l}\text { e beginnir } \\
\text { ties/fuels/1 } \\
\text { Categor } \\
\text { urniture, } \mathrm{f} \\
\text { des expen } \\
\text { vehicle in } \\
\\
\text { 4. } \\
\text { urban sta } \\
\text { ions also i } \\
\text { ent rate. }\end{array}$ & $\begin{array}{l}\text { f the } \\
\text { lic services. } \\
\text { includes } \\
\text { r coverings, } \\
\text { res on new } \\
\text { ance, public } \\
\text { number of } \\
\text { ude controls }\end{array}$ \\
\hline
\end{tabular}




\section{Table 6}

Weekly Ln Lotto Sales per Adult as a Function of Game Attributes

\begin{tabular}{|c|c|c|c|c|c|c|c|c|c|c|}
\hline $\begin{array}{l}\text { dep var: } \\
\ln \text { (pasales) }\end{array}$ & (1) & & (2) & & (3) & & (4) & & (5) & \\
\hline Expected value & $\begin{array}{c}.377 \\
(.406)\end{array}$ & & $\begin{array}{c}.683 \\
(.136)\end{array}$ & $* * *$ & $\begin{array}{l}.757 \\
(.126)\end{array}$ & $* * *$ & $\begin{array}{l}.299 \\
(.060)\end{array}$ & $* * *$ & $\begin{array}{l}.346 \\
(.060)\end{array}$ & $* * *$ \\
\hline Variance/1M. & $\begin{array}{c}.040 \\
(.010)\end{array}$ & $* * *$ & $\begin{array}{l}.003 \\
(.006)\end{array}$ & & $\begin{array}{l}-.006 \\
(.004)\end{array}$ & & $\begin{array}{c}.010 \\
(.001)\end{array}$ & $* * *$ & $\begin{array}{c}.004 \\
(.002)\end{array}$ & $* *$ \\
\hline skewness /1T & $\begin{array}{c}-.0002 \\
(.00005)\end{array}$ & $* * *$ & $\begin{array}{l}.000008 \\
(.00004)\end{array}$ & & $\begin{array}{l}.00003 \\
(.00003)\end{array}$ & & $\begin{array}{l}-.00004 \\
(.00001)\end{array}$ & $* * *$ & $\begin{array}{c}-.00001 \\
(.000007)\end{array}$ & $*$ \\
\hline $\begin{array}{l}\text { nominal top } \\
\text { prize/1M. }\end{array}$ & - & & - & & $\begin{array}{c}.007 \\
(.002)\end{array}$ & $* * *$ & - & & $\begin{array}{l}.004 \\
(.0008)\end{array}$ & $* * *$ \\
\hline no. draws per week & - & & $\begin{array}{l}-.059 \\
(.024)\end{array}$ & $* *$ & $\begin{array}{l}-.052 \\
(.024)\end{array}$ & $* *$ & - & & - & \\
\hline age of game & - & & $\begin{array}{l}-.133 \\
(.041)\end{array}$ & $* * *$ & $\begin{array}{l}-.126 \\
(.041)\end{array}$ & $* * *$ & $\begin{array}{l}-.201 \\
(.076)\end{array}$ & $* * *$ & $\begin{array}{l}-.206 \\
(.076)\end{array}$ & $* * *$ \\
\hline$(\text { age of game })^{2}$ & - & & $\begin{array}{l}.020 \\
(.004)\end{array}$ & $* * *$ & $\begin{array}{l}.020 \\
(.004)\end{array}$ & $* * *$ & $\begin{array}{l}.022 \\
(.003)\end{array}$ & $* * *$ & $\begin{array}{l}.023 \\
(.003)\end{array}$ & $* * *$ \\
\hline pick 5 & - & & $\begin{array}{l}.828 \\
(.154)\end{array}$ & $* * *$ & $\begin{array}{l}.785 \\
(.155)\end{array}$ & $* * *$ & - & & - & \\
\hline pick 6 & - & & $\begin{array}{l}.398 \\
(.151)\end{array}$ & $* * *$ & $\begin{array}{l}.401 \\
(.149)\end{array}$ & $* * *$ & - & & - & \\
\hline pick 7 & - & & $\begin{array}{c}.857 \\
(.182)\end{array}$ & $* * *$ & $\begin{array}{l}.823 \\
(.177)\end{array}$ & $* * *$ & - & & - & \\
\hline cash jackpot & - & & $\begin{array}{l}-1.13 \\
(.149)\end{array}$ & $* * *$ & $\begin{array}{l}-1.11 \\
(.143)\end{array}$ & $* * *$ & - & & - & \\
\hline choice (cash/ann) & - & & $\begin{array}{l}.290 \\
(.156)\end{array}$ & $*$ & $\begin{array}{l}.214 \\
(.157)\end{array}$ & & - & & - & \\
\hline $\begin{array}{l}\text { state } \\
\text { unemployment rate }\end{array}$ & $\begin{array}{l}-.030 \\
(.025)\end{array}$ & & $\begin{array}{l}-.029 \\
(.019)\end{array}$ & & $\begin{array}{l}-.030 \\
(.019)\end{array}$ & & $\begin{array}{l}-.029 \\
(.015)\end{array}$ & $*$ & $\begin{array}{l}-.029 \\
(.015)\end{array}$ & $*$ \\
\hline $\begin{array}{l}\text { product fixed } \\
\text { effects }\end{array}$ & no & & no & & no & & yes & & yes & \\
\hline state fixed effects & yes & & yes & & yes & & yes & & yes & \\
\hline week fixed effects & yes & & yes & & yes & & yes & & yes & \\
\hline demog. controls* & yes & & yes & & yes & & yes & & yes & \\
\hline constant & $\begin{array}{l}-380.8 \\
(142.9)\end{array}$ & $* * *$ & $\begin{array}{l}25.1 \\
(75.2)\end{array}$ & & $\begin{array}{l}11.7 \\
(72.9)\end{array}$ & & $\begin{array}{l}-129.1 \\
(66.7)\end{array}$ & & $\begin{array}{l}-127.7 \\
(66.8) \\
14669\end{array}$ & $*$ \\
\hline sample size & 14,669 & & 13,930 & & 13,930 & & 13,930 & & 14,669 & \\
\hline$R^{2}$ & .61 & & .89 & & .89 & & .92 & & .91 & \\
\hline \multicolumn{11}{|c|}{$\begin{array}{l}\text { notes: } \\
\text { 1. Unit of observation is state-week-game. } \\
\text { 2. The sample includes } 91 \text { lotto products from } 33 \text { states. } \\
\text { 3. Standard errors are adjusted for clustering at the state-year level, to flexibly account for correlations among errors. } \\
\text { 4. Lottery sales data are from Lefleurs inc. } \\
\text { 5. Data on game characteristics is compiled by author using information provided by state lottery associations. } \\
\text { 6. Monthly state unemployment data are from the Bureau of Labor Statistics. } \\
\text { 7. All regressions are population weighted. All regressions control for the proportion of the state population in the } \\
\text { following categories: females age } 18-24,25-44,45-64,64+\text {, males age } 18-24,25-44,65+\text {. Yearly state population } \\
\text { figures are from the U.S. Census Bureau. }\end{array}$} \\
\hline
\end{tabular}




\begin{tabular}{ll}
\hline \hline & \multicolumn{1}{c}{ State Lottery Implementation, by Year } \\
\hline \hline 1964 & New Hampshire \\
1967 & New York \\
& \\
1970 & New Jersey \\
1972 & Connecticut, Massachusetts, Michigan, Pennsylvania \\
1973 & Maryland \\
1974 & Illinois, Maine, Ohio, Rhode Island \\
1975 & Delaware \\
1978 & Vermont \\
1981 & Arizona \\
1982 & District of Columbia, Washington \\
1983 & Colorado \\
1985 & California, Iowa, Oregon \\
1986 & Missouri, West Virginia \\
1987 & Montana, Kansas, South Dakota \\
1988 & Virginia, Florida, Wisconsin \\
1989 & Idaho, Indiana, Kentucky \\
1990 & Minnesota \\
1991 & Louisiana \\
1992 & Texas \\
1993 & Nebraska, Georgia \\
1996 & New Mexico \\
\hline \hline
\end{tabular}




\begin{tabular}{|c|c|c|c|c|c|}
\hline \multicolumn{6}{|c|}{$\begin{array}{c}\text { Appendix Table } 2 \\
\text { Lottery Sales (in Year } 2000 \text { Dollars) }\end{array}$} \\
\hline & \multicolumn{2}{|c|}{ Mean state sales } & \multicolumn{3}{|c|}{ All states } \\
\hline & $\begin{array}{l}\text { Monthly total } \\
\text { (in millions) }\end{array}$ & $\begin{array}{c}\text { Monthly per } \\
\text { adult sales }\end{array}$ & $\begin{array}{l}\text { Yearly total } \\
\text { (in millions) }\end{array}$ & $\begin{array}{c}\text { No. of states } \\
\text { (inc. DC) with } \\
\text { lotteries } \\
\end{array}$ & $\begin{array}{c}\text { No. of states } \\
\text { reporting } \\
\text { sales }\end{array}$ \\
\hline Overall & 78.8 & 18.3 & 33,409 & - & - \\
\hline 1992 & 67.8 & 16.0 & 24,207 & 35 & 32 \\
\hline 1993 & 80.8 & 17.5 & 31,574 & 37 & 34 \\
\hline 1994 & 86.3 & 18.9 & 34,158 & 37 & 33 \\
\hline 1995 & 78.1 & 18.9 & 34,671 & 37 & 37 \\
\hline 1996 & 81.0 & 18.5 & 34,981 & 38 & 36 \\
\hline 1997 & 78.7 & 18.3 & 34,951 & 38 & 37 \\
\hline 1998 & 77.1 & 18.9 & 34,287 & 38 & 38 \\
\hline \multicolumn{6}{|c|}{$\begin{array}{l}\text { notes: } \\
\text { 1. Lottery sales data is from Lefleurs inc., who collects information from state lottery agencies. } \\
\text { 2. Population figures used for per adult calculations are BLS census population numbers. } \\
\text { 3. These figures reflect sales on all lottery games, including lotto, multi-state lotto, numbers, instant, keno, sports, } \\
\text { bingo, and VLT products. }\end{array}$} \\
\hline
\end{tabular}

